Pieter Labuschagne

Emeritus professor and Research Fellow, Departement of Political Sciences, University of South Africa.

Email: labuspa@unisa.ac.za

DOI: https://dx.doi. org/10.18820/24150509/ JCH43.v2.6

ISSN 0258-2422 (Print) ISSN 2415-0509 (Online) Journal for Contemporary History

2018 43(2):96-116

(c) Creative Commons With Attribution (CC-BY)

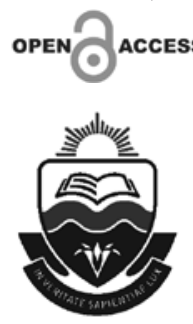

\section{SOUTH AFRICA, COALITION AND FORM OF GOVERNMENT: SEMI- PRESIDENTIALISM A TERTIUM GENUS?}

\begin{abstract}
The decline in support for the ruling ANC party in the 2016 municipal election has opened for the first time the likelihood of a coalition government in South Africa. However, there remain a number of questions and uncertainties regarding coalitions and their perceived success in providing stability. The formation of coalitions in parliamentary systems is well researched; however, many gaps exist in the available literature regarding coalitions in presidential systems and variations of presidential systems in South America. In both systems, the instability of coalition formation has raised fundamental questions about the interrelationship between the various forms of government and the success and duration of coalitions. The fundamental question is how well coalition governments in the different forms of government relate to fulfilling the goals of government stability, securing enduring legislative majorities, and encouraging democratic practices, including the ability to hold the shared leadership structure accountable. The article examines South Africa's form of government with the aim of ascertain its ability to accommodate a coalition.
\end{abstract}

Keywords: coalition; coalition government; form of government; presidential system; semi-presidential system; parliamentary system; minority party.

Sleutelwoorde: koalisie; koalisie regering; regeringsvorm; presidensiële stelsel; parlementêre stelsel; semipresidensiële stelsel; minderheidsparty. 


\section{INTRODUCTION}

Single party rule has dominated the South African political landscape for almost 70 years - so much, so that it closely resembled a one-party state. The prolonged period of one party dominance spanned from the post 1948 era, when the National Party (NP) came into power, until its replacement in 1994 by the African National Congress (ANC), who won the first democratic election in South Africa. During this period and up until the present, both parties had exerted a monopoly of power, with only limited challenges from opposition parties. There was no serious challenge for either the NP or the ANC at the ballot box. Their political ascendency came close to institutionalising a de facto one-party state. Both parties have conclusively demonstrated during the 70-year period that they had sufficient support and could govern without the assistance of any other party, or need to contemplate the formation of a coalition.

However, the year of 2016 could serve as a watershed or a turning point in the dynamics of domestic politics and of dominant one-party rule. Current developments and trends point to a shift of political alliances and a dynamic reconfiguration of support away from the ruling ANC party and in favour of opposition parties, such as the Democratic Alliance (DA) and the Economic Freedom Fighters (EFF). Nationwide support for the ANC in the municipal election in 2016 dropped by $8 \%$ and the party has lost control of three of the major metropoles, namely Johannesburg, Tshwane and Nelson Mandela Bay. In the three metro cities, coalitions and various forms of cooperation between opposition parties has allowed them to take over control of the municipalities. The decline in support has relegated the ANC to the opposition benches in these areas, and in many other municipalities there was a dramatic reduction in their support. In the aftermath of the election, the revelation of state corruption and state capture rock the party and that impact on their support and subsequent by-elections have showed that their downward trend in support continues (The Daily Maverick 2017: 5). However, with the difference in support at municipal and national level the 2019 election will be the real acid test.

The emergence of coalitions and different forms of cooperation between opposition parties in the three major mega cities suggest the possible dawn of a new era of governance in the country. The decline in support for the ruling ANC party has for the first time opened up the possibility of coalition governance as a viable alternative to what closely resembled de facto one-party rule. The decline in support for a single dominant party and the possibility of coalition formation, in turn, evoke a set of related questions regarding its potential impact on the political environment. The advent of coalition rule is normally associated with domestic instability and fluctuation, because of the fragmentation of political control and the lack of internal party cohesion. In an "ideal" scenario, 
a single majority party should emerge after an election and take over the reins of government. The absence of a clear winner and the formation of a coalition is thus, in reality, a second, less desirable outcome. The need for political coalitions is only required when a party, or a government, is in a minority situation and displays strong divisions, a lack of internal cohesion, and institutional instability in broader society.

When the need arises to form a coalition, there are two very important questions:

(i) The first question is a formal-technical challenge, which preludes the coalition as a form of partnership between two minority parties. The critical question is how, in the proposed coalition, leadership positions should be structured or shared between the two coalition partners. There are also additional requirements: the structuring of the coalition on all governmental levels, clarity on policy issues, and the question of electoral accountability.

Hellwig and Samuels (2007: 65) emphasise the fact that shared leadership in a coalition should primarily contemplate how and to what degree voters could potentially hold the shared leadership structure to account for their policies and actions.

(ii) The formation of a coalition is dependent on the underpinning precondition that the management structure (coalition) should be compatible and conducive to the existing political-institutional environment (form of government). In this political-institutional context, the coalition must be complementary and attuned to the existing form of government to allow maximum efficiency (Llianos 2006: 14).

\section{BACKGROUND TO THE RESEARCH QUESTION}

Cheibub, Przeworski and Saiegh (2004) emphasise the fact that coalitions are customarily associated with the parliamentary form of government. The reason is most probably because the parliamentary system's fused legislature and executive seems to be more conducive to the formation, accommodation and durability of coalitions. However, as the authors have indicated in their research, coalitions are by no means an unusual phenomenon as the other dominant form of government - the presidential system. Cheibut et al. collected substantial information about coalition governments between 1959 and 1999, and the results revealed an interesting picture. Empirical evidence in the study showed that where parliaments experience no clear majority party, the strongest minority 
party has formed coalitions in $78 \%$ of the cases. The interesting fact is that coalition formation in presidential systems occurs in 53,6\% of the cases where the strongest party did not enjoy an overall majority (Llanos 2006: 2).

However, although a coalition seems to be a desirable alternative to the strongest minority party, it is only a short or medium-term solution. In both parliamentary and presidential forms of government, coalitions have not translated to internal instability. The formation of coalitions in presidential forms of government, especially in countries in South America, revealed a higher level of instability and fragmentation than coalitions in parliamentary systems. The advantage seems to be located in the presence of a shared or fused system in parliament, as opposed to a more decentralised system such as the presidential system.

The formation of coalitions in parliamentary systems is well researched; however, there are still many gaps in the available literature regarding coalitions in presidential systems and variations of presidential systems in South America. The instability of coalition formation in both systems thus raises fundamental questions about the interrelationship between the various forms of government and the success and duration of coalitions. The fundamental question is how well coalition governments in the different forms of government relate to fulfilling the goals of government stability, the securing of enduring legislative majorities, and encouraging democratic practices, including the ability to hold the shared leadership structure accountable (Llanos 2006:2; Hellwig \& Samuels 2007: 65).

The success of a coalition is - to a large degree - dependent on the form of government to be accommodative and, in turn, the provision of stability. The alignment of the coalition with the form of government thus appear to be an important pre-requisite or a sin qua non to achieve durability and longevity for the coalition. The aims and challenges of the coalition - as indicated in the previous paragraph - are leadership accommodation, the cohesion of joint political goals, and accountability to their respective support bases. The structure and flexibility of the form of government should thus be taken into account and deserve careful consideration before entering into a coalition pact with an opposition party.

\section{THE CENTRAL QUESTION UNDERPINNING THE ARTICLE}

In the scholarly work regarding coalition formation, the focus seems to be predominately on the two dominant forms of government, namely the parliamentary and the presidential systems (Cheibub, Przeworski \& Saiegh (2004)). In the available literature, the third form of government, the semipresidential system, remains under-researched in relation to that of coalition 
formation. The potential and shortcomings of the semi-presidential system to provide the political-institutional structure to accommodate a coalition has received less scholarly attention. The observation is a surprising phenomenon, because the supple structure of the semi-presidential system provides various possibilities and permutation that seems to be better accustomed to accommodating and sustaining a coalition. The structure of a semi-presidential system makes provision for the duality of leadership positions of a president and a prime minister and the institutional potential to accommodate their respective powerbases. In a semi-presidential system, with its "compulsory" cohabitation between the two senior leadership positons, cooperation and consensus seeking is institutionally enforced between the two party leaders and their parties. These accommodative factors surpass the institutional ability of the more rigid forms of the parliamentary and presidential systems to house a coalition between two parties. The more flexible and fragmented structure of the semi-presidential system seems, on the surface, to be a more conducive political-institutional environment to creating a management structure in order to accommodate the needs of two or more parties in a coalition government (Schoesmith 2003: 231-252).

The central question or prerequisite in the article relates directly to this fundamental aspect, namely the importance of the alignment of the management structure (form of government) with the political institutional environment (coalition) to complement the stated goals of achieving a majority and ensuring stability in society.

The ruling ANC party's decline in support following the 2016 election and the looming 2019 election thus emphasised the reality of a future coalition. The perimeter of a coalition thus delimits the article and frames the underpinning research question, namely, how compatible is the current South African form of government with a political-institutional environment that is able to provide and sustain a stable and successful coalition.

In order to address the central question meaningfully, an investigation will be required to determine South Africa's current form of government. It is of paramount importance to ascertain the South African form of government in order to evaluate whether the existing form of government will be complementary and compatible to a potential coalition between political parties. The fundamental questions are whether a coalition will accentuate differences between the coalition partners, will a coalition be able to accommodate the different leadership positions within the form of government, and whether it will be able to accommodate the different policies and provide stability in the country. It is important to address these and other matters; otherwise, the coalition may undermine the level of democracy, erode the stability of the state, and corrode democratic consolidation. 
The following logically interrelated subheadings will contextualise and complement the central research question:

i. A brief theoretical outline of the concept of a coalition or coalition governments.

ii. A brief outline of the various forms of government, followed by an analytical analysis of the 1996 Constitution, with the aim of ascertaining South Africa's form of government.

iii. The first two sub-sections will then be enhanced by a short case study of Timor-Leste (former East-Timor), specifically focusing on the challenges of a coalition in dual leadership in a semipresidential system.

iv. In the concluding section, the form of government in South Africa and its potential ability and compatibility to sustain a coalition will be investigated - especially it's potential to deal successfully with the stated desirable outcomes.

\section{COALITION AND THE PROBLEMS OF A "FORCED" MARRIAGE}

The indispensable feature of a coalition is that it is essentially a form of cooperation between two political parties or groups, not because this is what they desire, but because of what they are compelled to do. In short, a coalition is the stepfather of single party rule that occurs when a party is unable to obtain the desired majority after an election and thus desires assistance from other parties in order to govern. Although it is possible to govern as a "minority party" in parliament in the absence of a preferred majority, it is the less desirable option. The 2017 British general election did not result in a clear majority and Prime Minister Theresa May was compelled to consider a coalition when her Conservative Party was unable to achieve a majority in the general election (Sunday Times 18 May 2017).

It is conceivable to govern as a minority party, but it remains a perpetual challenge to obtain the necessary support to govern and to pass legislation. The minority party remains vulnerable and dependent on some form of partnership with smaller parties to function and to survive.

The textbook definition of a coalition is the voluntary and temporary cooperation between two political parties that required joint support to be able to obtain a majority in parliament to govern the country. A coalition is an 
agreement by groups or political parties to govern jointly, to achieve a common goal, or to act in concert against an enemy or a political opponent. However, the driving force within a political-institutional context is predominately to achieve a parliamentary majority to be able to govern. The normal occurrence of a coalition is during a period of great uncertainty or political fluctuation and although not desirable, a coalition can bridge differences and provide a degree of stability in periods of domestic flux. In South Africa, the leader of the governing National Party, General Hertzog, formed a coalition in the 1930s with the South African Party of General Smuts to strengthen government amid an economic recession and political uncertainty (Schoonees 1976: 532).

The short concise definition of a coalition is a grouping of rival political actors brought together through the perception of a common threat or to harness collective energies. This is also in recognition of the fact that the achievement of their goals, individually and collectively, is not achievable by working separately, but only by joining forces. The hallmark of a coalition government is the intrinsic and complex set of negotiations that lead to conciliation. The trademark of the whole process is a search for common ground underpinned by a strong sense of necessity, rather than that of conviction. The criticism aimed at coalition formation is that it is essentially corrupt because it translates to working with the political enemy and deviating from the set party principles. A coalition often results in the over-presentation of the centrists' parties, but the importance of a coalition is that it has the inherent ability to address potential instability and to enhance effectiveness (Heywood 2009: 421).

Jackson and Jackson (2006: 241) point out that in Europe, with its unique party systems and factionalised parties, the formation of coalitions became almost a historical necessity for governments to rule. The formation of coalitions perpetually requires parties to obtain majority support in the assembly, form a cabinet and assume the title of head of government, and to, "continue with the business of governance".

The formation of a coalition between political parties can take two basic forms: a majority coalition, or a minority coalition/ alliance. In the case of a majority coalition, two or more parties with a majority of seats in the assembly join to form a government. This is the most common form of coalition government across continental Europe, especially in countries such as Finland, Germany, Belgium and the Netherlands. A minority coalition, or an alliance, is also possible and occurs where the parties collectively still lack a parliamentary majority. In Denmark, a minority coalition is a regular phenomenon. This was also the case in Italy before the transformation of its party system (Hague \& Harrop 2007: 233).

The problematic aspect of a coalition government is its inherent instability, because of its lack of internal cohesion and the fragmentation of individual 
political party goals. The contributing factor to the undercurrent of instability is that the parties are compelled to work together, not out of their own free will, but out of principle. The overall experience is that coalition governments can be notoriously fractured and unstable, with more time absorbed by internal squabbles among coalition partners than the task of governing. In post-war Italy, the country became notorious for its instability among the coalition partners, with a government lasting an average of ten months. However, there is a counterbalance against the failure of coalitions in Italy by the success of coalition governments in Germany and in Sweden (Heywood 2009: 241).

The parliamentary system is responsible for the most obvious and regular coalitions and its basic characteristics is the best institutional framework to enable a good chance of success for coalitions. The parliamentary system's basic logic is that it promotes cooperation and consensus within the context of coherent politics. The unification and fusion of the legislative and executive powers places a high premium on cooperation between coalition partners to maximise success and avoid the necessity for new elections (Llanos 2006: 5).

The presidential system, in direct contrast to the parliamentary system, generates or solicits a non-cooperative political style that tends to lead to a "winner takes all" outcome, which is likely to undermine the potential success of a coalition. The underpinning reason is that the successful presidential candidate in the election, and his party, lack the incentive to negotiate and share power, regardless of an absolute majority in the legislature. The strong emphasis on the separation of power, which detaches the president from the legislature, allows the presidency a large degree of independency. The president's party, which may be the minority party in the legislature, lacks the incentive to cooperate with the strongest party in the legislature, because the leadership knows that the president will concentrate on and control ultimate decisions. Coalitions among presidential systems are less frequent, and if formed, are rather short lived or are ad hoc coalitions, because the presence of undisciplined parties are the norm under presidentialism (Linz 1992).

The most fundamental problem with a coalition, which is common to both parliamentary and presidential systems, is the primary challenge of how, and at what level, to accommodate the coalition partner and its leadership structure. The accommodation includes the party's basic programme, its leadership, and the expectations of its support base to see their party's goals realised. Studies and scholarly work on parliamentary regimes suggest that coalition management is an important explanatory variable of coalition performance and is critical to its success. The challenges to form a coalition could be summarised as follows:

i. Agreement on the joint, properly prepared policy; agreement on the anticipated challenges, and how to deal with the problems. 
ii. A strong sense of fairness, for example, that the parties should receive parliamentary seats proportional to what they contribute to the coalition.

iii. The importance of coalition agreements - the arrangements the two coalition partners make before entering into executive branch collaboration.

iv. The importance of cooperation is that a sound agreement provides enough leeway to allow the cooperation to develop over a prolonged period. In a long-term coalition, the partners learn from the experience of working together with the same partners. In other words, a coalition with previous partners in practice in governments have a better chance of success (Llanos 2006: 5).

The allocation of seats, proportional to the contribution that the coalition parties made to the overall coalition, is very important. The position of the leader of the main coalition partner and its leadership, however, poses serious challenges to the arrangement. The arrangement should be placed on a firm footing as suggested above in points (i)-(iv), but it is ultimately the allocation of executive positions that threatens the success of the coalition.

It is the constitutional prerogative of the president in a presidential system to allocate executive positions, which could potentially be a major obstacle for coalition partners. In many presidential systems such as in Uruguay and in Chile, the allocation of the executive positions was crucial to the coalition's success. In a parliamentary system, parties and not individuals negotiate; this arrangement offers a solution to distributing leadership positions. (Llanos 2006: 5).

A challenge to both the parliamentary system and the presidential system is the vertically structured leadership, with a single focal point at the top in the form of a president or a prime minister (Duverger 1992: 115). The subservient leadership positions cascade down from the top position to form a pyramid and a vertical hierarchical leadership structure. The natural outcome is that an incoming coalition partner will always be in a subservient position, such as deputy prime minister - or in a presidential system, the Speaker of the House in the legislature.

The semi-presidential system, however, offers a more flexible alternative to the vertical hierarchical structure of the presidential and parliamentary systems. The presence of a dual leadership in the form of a president and a prime minster potentially offers a fairer distribution of senior positions in the politicalinstitutional arrangement. In the semi-presidential system, the leadership structure is horizontal and not vertical, having an asymmetrical structure with 
two focal points in the form of both a president and a prime minister (Blondel 1992: 160-172).

The availability of two positions, albeit in an asymmetrical structure, provides the potential and leeway to accommodate the party with the most seats to the position of president, and the coalition partner with the second most seats to the position of prime minister. This arrangement accommodates both leaders in prominent authoritative positions and forces them through the system of cohabitation to work together.

Blondel (1992: 160-172) accentuates the potential advantages of a dual leadership within the semi-presidential system, especially in a diverse and fragmented society. The most obvious advantage is the intrinsically imbedded decentralisation and flexibility of this form of rule in a semi-presidential system. Blondel (1992: 160-172) pointed out that the dual leadership is able to provide a combination of authority and flexibility that creates the political-institutional environment for a liberal regime that can accommodate and facilitate plurality in society. The system fosters cooperation in the form of a unique phenomenon of cohabitation within the institutional dual leadership.

The phenomenon of institutional cohabitation is unique to semi-presidential systems and occurs when the president and the prime minister come from different parties or from coalition partners. The president in the semi-presidential system has a stronger external role as the executive, dealing with international affairs, while the prime minister functions as the head of the legislature and fulfils a domestic leadership role. When the incumbents in the roles of president and prime minister are from different parties, they are compelled to function in concert in spite of differences in their roles based on a system of checks and balances. During 1986 and in 1993 the French Socialist President, Mitterrand, was compelled to function within the system of cohabitation with Gaullist governments led by Chirac as Prime Minister, when his party failed to gain a majority in parliament. The vulnerability of the presidential power and its dependency on legislative support was demonstrated when Chirac became president after Jospin's Socialist-led government came into power (Heywood 2009: 342).

The additional advantage of cohabitation is that the system clarifies electoral accountability with a clear link between the electorate and the functionary in office. When the president and the prime minister are from different parties in the coalition, the president is the effective head of government and voters could reward or punish both the president and his party. The prime minister is sharing executive responsibilities and voters could transfer performance evaluations onto the prime minister's party and ignore the president's party (Hellwig \& Samuels 2007: 70). 
The two centres of power in a semi-presidential system are more conducive to accommodating the leadership of the two coalition partners and, as indicated, create a clear line of electoral accountability that impacts on the leader. The challenge in a parliamentary system is that the regulatory fusion to accommodate the coalition parties in a vertical and not a horizontal asymmetrical position (as in a semi-presidential system) obscures the clear lines of accountability. The failure or success of the leaders in a vertical system, such as a parliamentary system, may either undermine the status of the prime minister or strengthen his position, which can in turn undermine the deputy position occupied by its coalition partner. In 2010, when the leader of the British Conservative Party, David Cameron, formed a coalition with Nick Clegg of the Liberal Democrats, the arrangement worked in his favour as the senior partner. The Conservative Party managed to consolidate its support because of the coalition arrangement and was able to rule and grow in this arrangement until the 2015 election. Cameron used the stability and majority as a springboard to win an outright election four years later. In contrast, the Liberal Democrats under Clegg's leadership paid heavily for its cooperation with the Conservative Party and he and his party ended up in a downward trend (Kettle 2007: 4).

In South Africa, the opposite happened when the more subservient position in the coalition benefited the most from the arrangement. General Hertzog formed a coalition in 1933 with General Smuts, whom he appointed as his deputy prime minister. Smuts very effectively used the power that the position afforded to him - and was elevated from being the leader of the opposition to holding the second most powerful position in the politics of the country. Smuts managed to force a standoff on the question of whether South Africa should participate in the Second World War, and then defeated Hertzog in a motion not to be neutral with 80 against 67 votes. In the ensuing political and constitutional developments, Smuts took over as prime minister, ousting Hertzog into the political wilderness (Geyser 2017: 232).

\section{SOUTH AFRICA'S FORM OF GOVERNMENT: PARLIAMENTARY OR TERTIUM GENUS (SEMI-PRESIDENTIAL)?}

The significance of the form of government in relation to the eventual success of a coalition to provide stability and cooperation is of paramount importance. It is critical that the form of government should complement the politicalinstitutional environment to accommodate a coalition government. The aim of this sub-section is thus to investigate South Africa's form of government and 
the various options regarding the potential to accommodate a possible coalition in 2019.

There is broad-based consensus in the available literature that the form of government during the pre-democratic period (1910-1994) in South Africa mirrored a typical Westminster style parliamentary system. The model of the South African form of government mimic, constitutionally and politically, the British mater parliament (Venter 1989: 111). The form of government displayed distinguishing Westminster features, including a government that governs in and through the assembly or parliament, thereby fusing the legislative and the executive branches. The institutional structure included the formation of a parliament based on the outcome of a general election and on the support for the respective parties. The leader of the strongest party occupied the position of prime minister, and the head of government had to select members from the assembly to form the cabinet.

The transformation of South Africa's political and institutional landscape in 1994 followed the democratisation of the country. The transformation thus offered a unique opportunity for the framers of the constitution to move from the previous "tyranny" of parliamentary sovereignty under the apartheid regime. Alex de Tocqueville, who studied the American Constitution, observed that the American Constitution was a great experiment and an, "opportunity to construct society on a new basis" (Law 2007:12).

The 1993 (interim) and 1996 (final) constitutions in South Africa have thus functioned as "founding documents" to construct a new political and constitutional dispensation to transform society. However, the interim (1993) and final (1996) constitutions did not specify the "new" form of government under the new constitutional dispensation (Basson 1993: 111). It is thus necessary to analyse the various provisions in the constitution to ascertain the form of government. Sections 87 to 91, and the procedures stipulated therein, however, left little uncertainty as to the form of government, because the provisions affirmed the retention of the fused status of the legislature and the executive. Parliament displayed fused legislature and executive bodies, which points to a parliamentary form of government distinct from the stronger separation of powers in a presidential system.

Devenish (2002: 115) concurred the retention of the parliamentary form of government, rather than reverting to a presidential system. This decision was, to a certain degree, peculiar against the background of the chequered history of parliamentary sovereignty under the apartheid regime. One reason for the decision to retain a parliamentary system was that the transformation process, from an apartheid state to a transformative regime, required an effective and strong government to transform society. A parliamentary system is routinely associated with a more effective and a stronger form of rule than the presidential 
system. The framers of the constitution thus refrained from a system with the tendency to gridlock in the manner of a presidential system when the opposition controls the independent and separate legislature.

However, although a fused parliament is a clear "give away" of the form of government, there are noticeable and significant deviations from a conventional parliamentary system. One of the first observations of the deviation is that the provision for a parliamentary system differs on a fundamental aspect from previous constitutions, namely the introduction of an executive president and not a prime minister.

i. Section 42(3): The election of the National Assembly is to represent the people and to ensure government by the people ... it does so by choosing a president.

ii. Section 87: When elected president, the person ceases to be a member of the National Assembly.

iii. Section 91(4)(b): The president must appoint a member of the cabinet to be the leader of government business in the National Assembly.

The initial indications are in favour of the view that a parliamentary system with a fused legislature and executive was retained (Rautenbach \& Malherbe 1996: 105). However, on closer inspection, it is noticeable that the 1996 Constitution contained subtle differences from its predecessors, which stray from the conventional parliamentary system. These constitutional deviations provide a formal indication of the potential to function and to develop further into a hybrid system - located between a parliamentary and a semi-presidential system.

The appointment of the executive leader, based on the 1996 Constitution, differs from the convention that applies in a pure parliamentary system. The Constitution stipulated that after the election the leader of the strongest party would not automatically function as head of the government. Section 86(1) required that during the first meeting of the Assembly, following the general election, the president is elected from its members. When a party has strong representation in parliament, this may be a foregone conclusion, but in the case of a marginal majority in the assembly, the outcome is not definite or guaranteed. It is conceivable that backbenchers of the majority may rebel and support the opposition in electing an opposition leader as the new president.

When section 86(1) is read together with section 42(3), it provides additional leeway for a more direct link between the electorate and the election of the president/prime minister, which deviates from conventional custom and procedure in a parliamentary system. In a parliamentary system, the leader of 
the strongest party is immediately elevated to the positon of prime minister without a subsequent election. The election of the leader of the majority party in a parliamentary system happens beforehand, through the party structures, either in a caucus or during a party's federal congress. If the party obtains the majority of the seats in parliament, the leader of the majority party functions as the prime minister/president and no further elections are required.

The 1996 Constitution, section 42(3), makes provision for an important deviation from this typical parliamentary characteristic by stipulating the following, "The election of the members of the National Assembly is to represent the people and to ensure government by the people ...it does so by choosing the president..." This allows the opportunity for the representatives of the people to elect the president, and although only in theory, to elect another candidate, who is not the leader of the majority party. This establishes a more direct line through the representatives of the people to the election of the president.

In a parliamentary system, party discipline normally translates to a situation where the leader of the majority party will immediately move into the position of prime minister. However, article 42(3) establishes a formal a link between the electorate and the election of the president. In a pure parliamentary system, this link is severed, because the election of the party leader is controlled by gate keeping within the party structures. The election takes place in the relative secrecy of a caucus or at a federal congress away from public scrutiny.

Section 91(4)(b) of the constitution makes provision for the next important deviation from a conventional parliamentary system to a hybrid system. The provision indicated that the president must appoint a member of the cabinet to be the leader of government business in the National Assembly. Section 87 stipulates that the president is no longer a member of the Assembly and must vacate his seat after his election. According to section 87, the leader of government business in the National Assembly, as appointed by the president, is thus the second most senior position. The importance of section 87 is the establishment of dual leadership and the formation of a second powerful position inside parliament. The presence of a dual leadership and the positioning of the leader of the legislature resembles a semi-presidential system and is significant.

The presence in the form of government of two of the important characteristics of the semi-presidential system is an indication of a hybrid system functionally located between the parliamentary and semi-presidential systems. One feature (the direct election of the president) is only partial, but the two centres of power serve as evidence of the presence of a sui generis form of government that deviates from the conventional parliamentary system. The form of government based on this evidence is a hybrid form, located between the two extremes on the continuum of a semi-presidential system. It is important to notice that the semi-presidential system covers a wide spectrum of permutations 
- from an all-powerful president to the opposite side where the president is just a figurehead.

Duverger (1992: 145) confirmed the permutations and also emphasised the fact that establishing a president, who is put into office by universal suffrage and endowed with personal (executive) powers, alongside a prime minister (leader of parliament) and a government resting on parliament, will, by definition, introduce dual leadership into the system. It also confirmed the system as a variant of the semi-presidential system as a form of government. The presence of section 91(4) and its evolutionary potential, as Duverger (1992: 146) puts it, states that, "...such constitutions introduce dualism into the heart of the system".

The semi-presidential system displays three basic variants that directly relate to the degree and balance of power between the president and the prime minister. The three variants could be summarised as follows (Beukman 2016: 65):

i. President-premier sub type of semi-presidentialism, as the first variant, has an over-powerful president controlling the majority in parliament or being in a position to dominate the premier. France is a good example of a president-premier system; however, in some instances, with a powerful opposition in parliament headed by a prime minister, the president needs to revert to cohabitation to get programmes and policies through parliament.

ii. Balanced presidency and government is a system with an equal distribution of power and the presence of the system of cohabitation. The best-known examples of the balanced presidency and government as a variant of the semi-presidential system were the former Weimar Republic and contemporary constitutional arrangements in Finland and in Portugal.

iii. Premier-presidential system is the third sub-type of semipresidentialism. It ranges from a premier who is in a strong position and the survival of government depends solely on parliamentary support, to where the position of the president in a premier-presidential system is weak and dependent on cohabitation to survive. In some extreme cases, the president is merely a figurehead (Austria, Ireland and Iceland) (Duverger 1992: 142-149; Beukman 2016: 65).

The categorising of South Africa's form of government in relation to the permutations above evidently exclude (iii) and the form is probably located between the president-premier and the balanced presidency and government systems. The position of president is powerful and resembles the president- 
premier sub-type, but there are elements of a balanced presidency and government present as a variant of a semi-presidential system (42(3) and section 91(4)(b)).

There are clearly significant departures from the parliamentary system toward a semi-presidential system. The first deviation from a pure parliamentary system is that the leader of the majority party automatically becomes the new prime minister and no formal election is required. The election or appointment of the leader/president in a semi-presidential system closely resembles the presidential system; the procedure makes provision for a separate direct election.

It is important to introduce a comparative scenario of a coalition within a semi-presidential system to get a better understanding of the complexities of such an arrangement. In order to investigate the matter more deeply, a case study of a coalition within a semi-presidential system will be analysed. In the next sub-section, the discussion will thus focus on a coalition and divided leadership in a semi-presidential system, with specific reference to the case study of East Timor - now Timor-Leste.

\section{DIVIDED LEADERSHIP IN A SEMI-PRESIDENTIAL SYSTEM- THE CASE OF TIMOR-LESTE}

The important and critical aspect for the success of dual leadership in a semipresidential system is cooperation based on the system of cohabitation. The preceding sub-sections outlined the compatibility and flexibility of a semipresidential system. In addition, the outline emphasised the semi-presidential system's ability to accommodate a coalition and to provide two centres of power for the two incumbent leaders in a coalition. However, the process of cohabitation must take place in a spirit of mutual consensus seeking and a genuine effort to reconcile opposing differences (Hellwig \& Samuels 2007: 70).

The aim of this sub-section is to introduce a short case study of TimorLeste (as East Timor was renamed) - the first new state of the 21st century. The case study serves to demonstrate how the establishment of a dual leadership in Timor-Leste attempted to accommodate plurality and diversity in a system of semi-presidentialism.

Timor-Leste simultaneously embarked on a process of state and democracy building, and to reach these goals the constitutional assembly adopted a system not present elsewhere in Southeast Asia. The system made provision for an elected president (fixed term) and a prime minister and a form of government that closely resembled a semi-presidential system. In Timor-Leste, a semi-presidential system has emerged with two power centres - an executive president, and the government headed by a prime minister located in parliament. 
The president and the prime minister each claimed a popular vote - confirmed in separate general elections in a system that resembles the premier-presidential sub-type of the semi-presidential system (Schoesmith 2003: 232; Beukman 2016: 21).

Dr. Alkari, as the leader of the Revolutionary Front for an Independent Timor (Fretilin), won 55 of the 88 seats in the Constituent Assembly in the first elections in 2001 after independence and occupied the position of prime minister. President Xanana Gusmă, who stood as an independent candidate, won the presidential election with $82 \%$ of the vote. The two candidates, one a former activist in exile and the other a former resistance leader, both made claim to nationalist and revolutionary legitimacy.

The aim of the dual leadership introduced by the semi-presidential system in Timor-Leste was to ensure cooperation and conciliation. The intention was for the inherent process of cohabitation to diminish differences between the two positions and not to accentuate fault lines in the politics of the region. However, the two incumbents were bitter political enemies and acrimonious rivals. It is unnecessary for the purpose of the article to venture into the historical differences between the two leaders, but it suffices to say that the differences defeated the purpose of the flexible system with the potential to smooth over the plurality and conflict. The acrimony between the two leaders in Timor-Leste reaffirmed the opposite; the system of dual leadership, unfortunately, also has the potential to accentuate differences between coalition partners. The adoption of the semi-presidential system and the introduction of dual leaders created a rivalry within the national leadership that frustrated efforts to create an effective and democratic state in Timor. As the government grappled with the challenge to combine disciplined governance with democratic principles, the prime minister's priority should have been to centralise state power under his party control; the president's priority was democratic accountability in the pluralists' party system (Schoesmith 2003: 232).

The problem in Timor-Leste was that the presidents did not have a majority in parliament, because the three presidents, during consecutive elections, fought, the independent separate elections as independent candidates. In a normal process of cohabitation, the prime minister and president have to reconcile, because they belong to different parties. In Timor-Leste, the semi-presidential system has witnessed six governments in 14 years, but the stability that the semi-presidential system provided is located in the fact that all the parliaments have completed their full terms. The presidents played a leading role in the process of checks, balances, and horizontal accountability that lay at the heart of democratic policies (Beukman 2016: 120). 


\section{TWO LEADERS, TWO POSITIONS AND DUAL LEADERSHIP}

In South Africa's current form of government the position of the premier, as leader of the Assembly, is not strongly developed. The Constitution section 91(4)(b) stipulates: The president must appoint a member of the cabinet to be the leader of government business in the National Assembly. There is no direct evidence that the incumbent is acting in the role of a prime minister.

However, the subservient position does not exclude its evolutionary potential to increase in power in the future, especially if support in parliament shifts away from the president. If a split developed between the president and the leader of the assembly, and the support within the party became fragmented, it could enhance the development of the system of government closer to the balanced presidency and government.

In the current political scenario, the incumbents of the position of prime minister and the leader of the Assembly are both from the strongest party. However, the situation could change when the president is - for a variety of reasons - no longer the de facto or de jure, leader of the party, which will then equate to shared leadership and a dualism of power in the system. This occurred in 1989 when PW Botha decided to step down as leader of the National Party, but decided to remain in the position of president. FW de Klerk stepped forward as leader of the National Party and formed a second locus of power in Parliament (De Klerk 2010: 115). Botha functioned as executive leader for a while, before the situation became untenable and incompatible within the political and institutional environment. The same development occurred in the ANC when the party elected Jacob Zuma as the leader of the party and Thabo Mbeki was the incumbent president. This scenario also instigated a dual leadership or two centres of power in the system. History repeated itself when Cyril Ramphosa was elected leader of the ANC and Jacob Zuma remained President.

If, and when, the declining support for the ruling ANC party forces the formation of a coalition, the paramount question will be the compatibility and inherent ability of the current form of government to be attuned and complementary to the rigorous nature of a coalition government.

The balanced presidency and government subtype, as a variant of a semi-presidential form of government, offers a compatible system that has the potential to deal with the demands of coalition partners with the availability of a two-leadership position, within a dual leadership scenario. The advantages of the quoted provisions in the constitution for coalition are multiple, namely two centres of power and authority (president and prime minister), the potential of the voters to hold each segment (legislative or presidential) accountable, and the "indirect election" of the president.

Thus, if the outcome of the 2019 election requires the formation of a coalition, the status of the leader of the assembly could develop as a de facto and 
de jure prime minster. The balanced presidency and government system clearly offers more flexibility in order to accommodate a potential coalition. In TimorLeste, two centres of power was achieved by appointing the leader of the second strongest party to the position of prime minister, who then managed to construct a post-electoral majoritarian platform and consequently relegated the largest party to the opposition (Beukman 2016: 99).

However, in spite of how lucrative the option of two centres of power and authority may seem to be, to accommodate the leadership hierarchy of a coalition in a divided leadership situation is not without pitfalls. The dual leadership may accommodate and address seniority in the two coalition partners, but this may also translate into instability if there is a high level of acrimony between the two incumbents.

\section{CONCLUSION}

In South Africa, the ruling ANC party's declining support raised for the first time since the first democratic election, the possibility of a coalition between two or more parties. The possibility of a coalition necessitates an investigation of the current form of governments' ability or capability - both structurally and functionally - to accommodate and facilitate a successful coalition.

The first step in the process was to determine South Africa's form of government and it was apparent that there are noticeable deviations in the Constitution from a conventional parliamentary system to a hybrid system located closer to the semi-presidential system. The cohesion of the ruling ANC party up to this point has inhibited the stronger evolutionary development of the position of the leader of the Assembly (potential prime minister) for a long period. However, if the president loses the support of his party, the current system could allow the leader of the Assembly to develop in a stronger, more assertive position. The development of the position of the leader of the Assembly could move the form of government closer to a balanced presidency and government. The development has the potential to "institutionalise conflict", but the concept of cohabitation should deal with opposing and conflicting views. In this scenario, it will enhance the diversity and plurality of the broader population as opposed to the current concentration of power within a single ruling party.

The formation of a coalition between two parties necessitates the accommodation of the two leaders in a system where both enjoy power, status and seniority. In such a scenario, the leader of the strongest party could occupy the position of president and the leader of the remaining party, could occupy the position of prime minister. The inclusion of more coalition partners could ensure that no single party has the majority in the Assembly, which could enhance the ideals of plurality and diversity in a country such as South Africa. 


\section{LIST OF SOURCES}

Basson D 1995. South Africa's Interim Constitution, text and notes. Cape Town: Juta \& Co.

Beuman LM 2016. Political institutions in East Timor: Semi-presidentialism and democratization. Oxon: Routledge. https://doi.org/10.4324/9781315668772

Blondel J 1992. Dual Leadership in the contemporary world in parliamentary versus presidential government, edited by A Lijphart. London: Oxford University Press.

Cheibub J 2002. "Minority governments, deadlock situations and the survival of presidential systems". Comparative Political Studies 35(3): 284-312. https:// doi.org/10.1177/0010414002035003002

Cheibub J \& A Przeworski, S Saiegh 2004. "Government coalitions and legislative success under parliamentary and presidential systems". British Journal of Political Sciences 34(4): 565-587. https://doi.org/10.1017/ S0007123404000195

Daily Maverick, 15 March 2017

Devenish G 2002. A commentary on the South African Constitution. Durban: Butterworths.

Duverger M 1992. A new systems model in parliamentary versus presidential government, edited by A. Lijphart. London: Oxford University Press.

Geyser 0 2017. Smuts en Hertzog in Jan Smuts: Die man van sy tyd. Edited by DJ Kriek. Pretoria: Protea Uitgewers.

Hague R \& M Harrop 2007. Comparative government and politics: An introduction. London: Palgrave and McMillan.

Hellwig T \& D Samuels 2007. "Electoral Accountability and the Variety of Democratic Regimes". British Journal of Political Sciences 38: 65-90.

Heywood A 2009. Politics. London: McMillan Press.

Jackson D \& J Jackson 2006. An Introduction to Political Science. Toronto: Prentice Hall.

Kettle D 2017. Conservative and Liberal coalition, accessed 15 June, <https:// www.theguardian.com-commentsfrees.

Law S 2007. Great philosopher. London: MacMillan Press.

Linz J 1992. The virtues of presidentialism in parliamentary versus presidential government, edited by A Lijphart. London: Oxford University Press. 
Llanos M 2006. Explaining coalition in presidential systems: The importance of (a parliamentary-style). Coalition management. Paper presented at the European Consortium of Political Research.

Rautenbach I \& R Malherbe 1996. Constitutional Law. Durban: Butterworths.

Schoonees PJ 1976. Verklarende Woordeboek. Kaapstad: Nasionale Pers.

Shoesmith D 2003. "Timor Leste: Divided Leadership in a Semi-Presidential System". Asian Survey 43(2): 231-252. https://doi.org/10.1525/as.2003.43.2.231

The Sunday Times, 18 May 2017.

Venter A 1989. South African government and politics. Johannesburg: Southern Book Publishers. 